\title{
ИНОВАЦИЈЕ У ОРУЖАНИМ СНАГАМА КАО ПРЕДУСЛОВ ЗА ЈАЧАҢЕ СТРАТЕШКЕ ЕФИКАСНОСТИ НАЦИЈЕ ${ }^{1}$
}

\author{
мср Вангел Милковски ${ }^{2}$ \\ мср Милан Џамић
}

\section{Апстракт}

Један од савремених изазова са којим се суочавају државе је прилагођавање комплексним променама у стратешком окружењу. Оружане снаге као инструмент војне националне моћи од велике важности су за очување националне безбедности, па су иновације у оружаним снагама неопходне за стварање услова очувања националних интереса. Развој способности оружаних снага је скуп и дуготрајан процес и због тога је временом постао предмет интересовања, не само оружаних снага, већ и академске јавности. Иновације у оружаним снагама као извор развоја нових способности постале су посебна целина у оквиру стратешких и одбрамбених студија високоразвијених земаља. Студије о иновацијама у оружаним снагама баве се трагањем за одговорима на три кључна питања: када, како и зашто се оружане снаге мењају, који су унутрашњи и спољашњи фактори који одређују начине иновација у оружаним снагама, шта и како одређује успешност иновација. Промене у оружаним снагама више не могу бити прилагођавање појединих делова и система, већ оружане снаге морају развијати способности за иновирање, што ће им помоћи да овладају новом парадигмом у одбрани и заштити националних интереса у константно променљивом стратешком окружењу. Аутори указују на то да без иновација нема потребних способности оружаних снага и да постоји потреба за њиховим академским проучавањем ради повећања укупне стратешке ефикасности нације.

Кључне речи: иновације, оружане снаге, стратегија, стратешко окружење, стратешка ефикасност нације

1 Погледи изнети у чланку одражавају лични став аутора, а не институција у којима су запослени.

2 Школа националне одбране, Универзитет одбране. Е-пошта: vmilkovski@gmail.com

3 Војнобезбедносна агенција, Министарство одбране Републике Србије. 


\section{УВод}

Иновације у оружаним снагама су дошле у први план политичких и војних дебата у великом броју земаља на свету услед промена у стратешком окружењу и степену технолошких измена. Оне су кључне за развој и одржавање војне моћи јер је војна моћ и даље од великог значаја за очување националне безбедности у променљивом динамичном, неизвесном и конкурентном стратешком окружењу. 4

Хари Јаргер (Harry R. Yarger) дефинише стратешко окружење државе као област у којој њено руководство сарађује са другим државама или актерима ради очувања, унапређења и остварења националних интереса. Ово окружење се састоји од унутрашњег и спољашњег контекста, услова, односа, трендова, питања, претњи, прилика, интеракције и ефеката који утичу на успех државе у односу према физичком свету, другим стањима и актерима, шансама и могућим условима у будућности. 5

Уважавајући чињеницу да постоји добро развијена расправа о значењу и примени појмова као што су „велика стратегија“, „национална стратегија“, „војна стратегија“ или само појам „стратегија“, за потребе разматрања иновација у оружаним снагама, стратегија се може дефинисати као тачка у којој се политичко и војно укрштају. Формулисањем и применом стратегије, државе настоје да изазову посебне ефекте у стратешком окружењу. То је динамично окружење које „реагује на улаз, али не нужно и на директан узрочно-последични начин“.6 У том смислу, стратегија је оно што политици обезбеђује дефинисане начине ангажовања инструмената националне моћи, а оружаним снагама и другим инструментима националне моћи циљеве деловања. Било која стратегија, формулисана или спроведена, уводи промене у стратешко окружење, чак и када тежи да одржи status quo. Те промене могу да изазову поремећај у постојећој равнотежи у стратешком окружењу. Стратегија не може предвидети будућност са апсолутном сигурношћу постизања својих циљева, нити прецизне последице достигнућа или неуспеха. Ефекти ${ }^{7}$ постигнути у имплементацији стратегије су кумулативни из неколико различитих перспектива, а посебно из перспективе промена. Промене постају део стратешког окружења и резултат су деловања различитих инструмената националне моћи. Намеравани резултати деловања

4 Stephen J. Gerras, Strategic Leadership Primer 3rd Edition, US Army War College, Carlisle Barracks, 2010, https://publications.armywarcollege.edu/pubs/3516.pdf

${ }^{5}$ Harry R. Yarger, Strategic Theory for The 21st Century: The Little Book On Big Strategy, February 2006,

https://www.files.ethz.ch/isn/20753/Strategic\%20Theory\%20for\%20the\%2021st\%20Centur y.pdf, $17 / 09 / 2020$

${ }^{6}$ Ibid.

7 Ефекат (effect) 1. Физичко или бихејвиорално стање система које је резултат радње, скупа радњи или другог ефекта; 2. Резултат, исход или последица радње; 3. Промена стања, понашања или степена слободе. Dictionary of Military and Associated Terms, Доступно на: https://www.jcs.mil/Portals/36/Documents/Doctrine/pubs/dictionary.pdf 
доступних инструмената моћи државе, по унапред утврђеним начинима, огледају се у политичким, економским, социјалним, етичким и другим условима који владају у димензијама стратешког окружења и које највише политичко и војно руководство жели да креира применом стратегије. Другачије речено, намеравани резултати представљају жељено крајње стање (резултате) деловања. Усмеравање инструмената националне моћи на циљеве, без јасно утврђеног стратешког жељеног крајњег стања из којих ти циљеви произилазе, смањују ефективност стратегије. Стратешки жељена крајња стања и циљеви истински су фокус у формулацији стратегије и ако нису правилно одабрани и артикулисани, предложена стратегија суштински је мањкава и не може бити ефективна. У том смислу, стратешки жељена крајња стања и циљеви су важни јер нам указују на то да ли радимо добру ствар, док начини деловања и инструменти националне моћи одређују ефикасност. Недостатак ефикасности повећава трошкове у примени стратегије, а недостатак ефективности отежава постизање успеха.

Оружане снаге као организација и структура војних ресурса једне државе представљају важан инструмент националне моћи. Државе на основу дефинисаних интереса и циљева, а у складу са сопственим могућностима, формирају и развијају оружане снаге, које у процесу организовања, опремања и оспособљавања изграђују потребне способности за достизање пројектованих циљева. Улога оружаних снага је да на основу формулисане војне стратегије остваре војне циљеве и тиме допринесу стварању повољних услова за остварење националних интереса државе. Другачије речено, улога оружаних снага је да допринесе стратешкој ефикасности стратегије.

Због тога су иновације у оружаним снагама неопходне јер у противном, стагнација и недовољне способности оружаних снага могу резултирати смањењем могућности очувања, достизања и одбране националних интереса. Разумевање иновација у оружаним снагама је сложено због чињенице да не постоји јединствена дефиниција појма која би означила начине на које оружане снаге повећавају своје способности и тиме стварају битне предуслове за постизање ефикасности одабране стратегије државе. Постоји више питања на које је потребно дати одговоре зарад разумевања иновације у војној делатности: шта су иновације у оружаним снагама, шта их покреће, који је најбољи начин за њихову реализацију и какве су стратешке импликације примене резултата иновација у неизвесном и комплексном стратешком окружењу. У трагању за одговорима на наведена питања могу да помогну основна сазнања о иновацијама у комерцијалном сектору.

\section{ИНОВАЦИЈЕ У КОМЕРЦИЈАЛНОМ СЕКТОРУ}

Традиционалне студије о иновацијама у комерцијалном сектору инспирисане су трагањем за одговорима на питања како произвести боље производе, повећати профит и ефикасност, освојити тржиште и искористити шансе за даљи развој. У свету предузетништва одржавање конкурентске предности и управљање променама су важни за опстанак на тржишту. У комерцијалном свету актери се 
надмећу једни против других, борећи се за наклоност купаца на тржишту, док се оружане снаге директно надмећу једна против друге у комплексном, непредвидивом и неизвесном окружењу које чини бојиште. Оружане снаге једне нације не би смеле себи да приуште стагнацију и ризик од катастрофалног пораза од потенцијалног противника.

Иновација се може дефинисати на више начина, али једноставно речено, то је стварање нечег новог - било да се ради о новом производу или уређају, другачијем начину организовања људи или ентитета, изворном процесу или методу вршења пословних процеса, или чак другачијој употреби постојећег предмета. Иновација је резултат критичког и креативног размишљања и претварања нових идеја у нове производе и процесе. Иако су идеје важан део концепта, појам иновација обухвата много више и захтева да се мисао трансформише у акцију и практичну употребу. „Уопште узев, иновације можемо тумачити као креативни процес у којем се две или више постојећих чињеница комбинују на нов начин а са циљем да се произведу нове вредности“.8 Дакле, иновација представља „трансформацију нових идеја у тржишно прихватљиве производе и услуге“.9 Иновација подразумева промену, али свака промена није per se иновативног карактера. Новине указују на то да је дошло до промене која може бити резултат утицаја различитих фактора из спољашњег и унутрашњег окружења. Дакле, иновације и промене су чврсто повезане. Успешне иновације неминовно воде ка значајном степену промена.

Иновације у комерцијалном сектору могу бити различитог облика, обухватајући различите компоненте пословног система у целости или његових појединачних делова. Анализирајући литературу која се бави иновацијама у комерцијалном сектору, Џон Гартска (John Gartska) указује на чињеницу да се иновације морају сагледавати у контексту међусобних спрега бројних саставних компоненти и целине пословног система. 10 Многи модели јасно су идентификовали да су технологија, процеси, организација и људи четири различита, али међусобно повезана подручја у којима су могуће иновације. Иновације у оквиру технологије и процеса сматрају се примарним изворима конкурентске предности, предности на тржишту, јер директно утичу на развој и усавршавање добара и услуга, а иновације у областима људи и организације се посматрају као индиректни извори конкурентске предности. ${ }^{11}$

8 Слободан Покрајац, Менацмент промена и промене менацмента, Тору, Београд, 2001, стр. 80.

9 Ненад Пенезић, Предузетништво - савремени приступ, Академска књига, Нови Сад, 2008, стр. 190.

10 John J. Garstka, „Conceptual Framework for Innovation in Capability Development”, Crosscutting Issues in International Transformation: Interactions and Innovations among People, Organizations, Processes, and Technology, ed. Derrick Neal, Henrik Friman, Ralph Doughty, and Linton Wells II, 21-5, Center for Technology and National Security Policy, Washington, DC, 2009. 11 Ibid. 
Иновације се могу разликовати у знатној мери, почев од оних које су потпуно нове и другачије од свега што је у претходном периоду било на располагању људима, па све до оних које укључују нешто више од мањих промена већ постојећих решења. ${ }^{12}$ Код првих, степен новине је велики, док је код других он незнатан. Ова разлика између великих и релативно малих новина садржаних у иновацијама инспирисала је један број аналитичара да направе дистинкцију између великих (радикалних) и малих (инкременталних) иновација. Према овом начину груписања иновација, групу радикалних иновација чине велика научна открића, нове технологије и велики технолошки проналасци. Мање иновације, попут побољшања перформанси производа, услуга и процеса, биће сврстане у групу инкременталних иновација. Полазећи од егзистирајућих разлика између делова система и система као целине, могуће је разликовати инкременталне, модуларне, компоненте и радикалне иновације. Код радикалних иновација долази до промена у деловима и архитектури система а код инкременталних до мањих промена које унапређују перформансе појединих компоненти. Клејтон Кристенсен (Clayton Christensen) указује да нека предузећа, и поред чињенице да успешно иновирају, могу да доживе неуспех у односу на одређене врсте конкурентских изазова. На ово питање одговара увођењем концепата одрживих и „ометајућих“ (енг. disruptive) иновација. Одрживе иновације стварају или побољшавају производе или услуге на начине које купци већ цене, док „ометајуће“ иновације стварају потпуно ново тржиште кроз представљање производа или услуге чији учинак у почетку не задовољава основне критеријуме које вреднују редовни купци. ${ }^{13}$ „Ометајуће“ иновације се појављују толико ретко да мало која компанија има рутински поступак за бављење њима и готово увек су у супротности са успостављеним пословним моделима и вредностима организације.

\section{ИНОВАЦИЈЕ У ОРУЖАНИМ СНАГАМА}

Инкременталне, модуларне, компонентне и радикалне иновације препознатљиве су и у оружаним снагама. Инкременталне иновације се најчешће везују за побољшање постојећих система наоружања и војне опреме (развој тенкова, авиона прве, друге, треће, четврте и пете генерације и сл.). Модуларне иновације видљиве су на примерима промена погонског горива за војне бродове (од угља и нафте до нуклеарног погона), затим у комуникацијама од аналогне до дигиталне технологије и сл. Компонентне иновације представљају новине и промене које су на бојишту изазвали митраљез, авион, тенк, балистички пројектили и сл. Радикалне иновације мењају целокупан начин ратовања, као што је случај са

12 Clayton Christenssen, The Innovator's Dilemma: When New Technologies Cause Great Firms to Fail, MA: Harvard Business School Press, Boston, 1997.

13 Ibid. 
амфибијским ратом, муњевитим ратом (blitzkrieg) или ратовањем у сајберпростору.

Иновације у оружаним снагама могу се посматрати и кроз призму карактеристика одрживих и „ометајућих“ иновација. Одрживе иновације побољшавају перформансе постојећих система у преовлађујућој физиономији рата. Примери подразумевају побољшања војних бродова у домену заштите и домета, повећању домета и прецизности артиљеријских, ракетних и балистичких средстава и сл. "Ометајуће“ иновације стварају нове способности које драстично увећавају способности оружаних снага и на неки начин изазивају постојећу парадигму у војној делатности и рату. Промена парадигме у физиономији рата и војним операцијама изазвана „ометајућим“ иновацијама може да:

- чини застарелом или ирелевантном једну или више основних способности оружаних снага (појава носача авиона и њихова употреба од стране Јапана на почетку Другог светског рата),

- ствара једну или више способности у некој новој димензији оперативног окружења (појава интерконтиненталних балистичких пројектила) или

- узрокује комбинацију претходно наведених начина за промене, као што је случај са концептом ратовања Маринског корпуса САД операционализованог у поморско-ваздушно-копненим борбеним групама (Marine Air Ground Task Forces - MAGTF USMC).

„Ометајуће“ иновације у војним пословима најчешће се сагледавају у призми совјетских војно-техничких револуција или америчких револуција у војним пословима. Расправа о томе шта представљају војно-техничке револуције (ВТР) или револуције у војним пословима (РВП) у ширем контексту иновација у војној делатности трасирала је нови пут у стратешким студијама током последње две деценије. Без обзира на различите дефиниције и школе мишљења које су еволуирале око сваког концептуалног појма, све школе мишљења се слажу са тим да се ради о важном стратешком концепту који представља синоним за „дисконтинуирану“ или „ометајућу“ иновацију у карактеру и вођењу рата. Од својих раних почетака као теорије ВТР совјетских стратешких мислилаца раних 1980-их, до ширих контура америчке одбрамбене трансформације раних 2000-их у САД, основне визије будућег ратовања биле су усидрене у трајном прелазу парадигме са „индустријализације“ на „информационо доба“, како тврде Тофлери (Heidi, Alvin Toffler). Наведени аутори тврде да се револуција у војним пословима, у свом пуном смислу, догађа онда када нова цивилизација изазове стару, када се цело друштво трансформише, присиљавајући своје оружане снаге да се промене на свим нивоима истовремено - од технологије и културе до организације, стратегије, тактике, обуке, доктрине и логистике. ${ }^{14}$ Тако би у постмодерно доба оружане снаге требало да следе најбоље праксе информатичког друштва у настајању - концептуалне, организационе и технолошке.

14 Види шире: Алвин и Хајди Тофлер, Pam и антират, Паидеиа, Београд, 1998. 
Већина иновација у војној делатности кроз историју несумњиво је следила мање различит револуционарни или трансформациони пут, који се састоји од постепених, често готово континуираних побољшања постојећих способности оружаних снага. Другим речима, док су велике и истовремене иновације у технологијама, организацијама и доктринама ретка појава, оружане снаге су напредовале кроз континуирани спектар иновација које су обликовале вођење рата. Иновације у оружаним снагама најчешће су еволутивне природе, а промене карактерише надоградња или побољшање постојећих војних способности у четири елемента: технологија, процеси, организација и људи.

Иновације у технологији битне су јер се њима развијају нови системи наоружања. Нове технологије у оружаним снагама имају потенцијал да промене „постојећа правила игре“ и „равнотежу војне моћи“ између актера у стратешком окружењу. Визија развоја способности оружаних снага готово увек има технолошки елемент. Савремени трендови доказују да се постојећа трка у наоружању огледа у развоју нових технологија као што су: вештачка интелигенција, аутономни борбени системи, нанотехнолошки сензори, усмерено енергетско оружје, хиперсонични пројектили и сл.

Иновације у доктрини оружаних снага су директна последица резултата у технолошким иновацијама. Нове способности оружаних снага омогућавају деловање на „другачији“ начин од уобичајеног. Иновације у технологији довеле су до повећане брзине и прецизности оружаних снага у свим димензијама окружења, које поред традиционалних укључује и димензије електромагнетног спектра, сајбер-простора и свемира. У таквом окружењу принципи употребе оружаних снага добијају нова значења и другачију практичну операционализацију у доктрини оружаних снага.

Иновација у организацији оружаних снага препозната је у принципу здруживања 15 и обједињавању различитих способности видова и родова оружаних снага. Тенденције указују да се способности које су традиционално припадале једном виду оружаних снага (копненој, ваздухопловној или поморској компоненти) сједињују на нижим тактичким нивоима организовања снага и на тај начин формирају организацијске целине способне за деловање у више димензија окружења.

Иновације у људском фактору подразумевају стварање нових вештина и знања код припадника оружаних снага, оне стварају нове начине за развој, мотивацију и задржавање људи у оружаним снагама, као и успостављање или побољшавање организације и организационе културе у њима.

15 Појам здруженост (jointness) представља неологизам настао у оружаним снагама САД како би се описала сарадња видова у свим фазама одређеног војног процеса. Изведен је од појма здружен (joint) који означава „активност, операцију и организацију, у којој се ангажују два или више вида“. Joint Doctrine Development System CJCSI 5120.02C (18. јун 2020); Доступно на: http://www.jcs.mil>pubs PDF (18.6.2020.) 
Комбинација иновативних процеса у ова четири елемента пружа увид у управљање иновацијама и уједно представља модел за разумевање улоге различитих врста иновација у развоју војних способности.

Историјски и емпиријски докази показују много шире варијације у изворима, путевима и обрасцима војних иновација, од развоја нових или различитих инструмената (технологија), пракси (доктрина и оперативни концепти), до формирања нових организационих структура снага, што је довело до детаљнијег и опширнијег проучавања иновација у оружаним снагама.

\section{СТУДИЈЕ О ИНОВАЦИЈАМА У ОРУЖАНИМ СНАГАМА}

Студије о иновацијама у оружаним снагама баве се питањима зашто, како и на који начин нације праве велике иновације у начину организовања, опремања и употребе оружаних снага и шта их покреће. Трагање за ефикаснијим начинима организовања и употребе оружаних снага нису новијег датума. Бележећи дешавања из ере Наполеоновог ратовања, Карл фон Клаузевиц (Carl von Clausewitz) иновацију у оружаним снагама је описивао као линеаран процес опонашања и прилагођавања ефикасне праксе на бојном пољу: „Ако се у ратовању покаже да је одређено средство високо ефикасно, биће поново употребљено; копираће га други и постаће модерно, и тако, поткрепљено искуством, прелази у општу употребу и укључује се у теорију“.16 Иако Клаузевиц није објаснио како искуство са бојног поља може постати организациона пракса или зашто неке војске уче из праксе, а неке не, он је приметио да постоје најмање три начина учења из праксе: историјски примери (сопствених оружаних снага и других), лично ратно искуство и искуство других оружаних снага.

Војни историчари, који истражују и документују јединствене иновацијске случајеве, покушавају да објасне како државе успевају или не успевају да трансформишу своје оружане снаге. Војни историчар и филозоф Азар Гат (Azar Gat) наглашава да се током периода „великих историјских изазова“ или „у доба кризе“ појављују нове идеје, које изражавају „људски напор да се уклопе са новим дешавањима и интегришу их у смислене интелектуалне оквире“.17 Бери Вотс (Barry Watts) и Вилијамсон Mapej (Williamson Murray) виде основну сврху студија о иновацијама у оружаним снагама као „помагање доносиоцима одлука да креативно размишљају о променама у природи рата које се могу догодити у наредним деценијама“, а не само као проучавање „историјских епизода“.18

${ }^{16}$ Carl Von Clausewitz, On War, Edited and Translated by Michael Howard and Peter

Paret,Princeton University Press, Princeton, New Jersey, 1989, p 171.

17 Azar Gat, The Development of Military Thought: The Fourteenth Century, Oxford University Press, New York, 1991, p. 247.

18 Barry Watts and Williamson Murray, „Military Innovation in Peacetim“ in: Williamson Murray and Allan R. Millett (eds.), Military Innovation in the Interwar Period, Cambridge University Press, New York, 1996, p. 371. 
Политиколог Бери Позен (Barry Posen) дефинише иновацију у оружаним снагама као велику промену која произлази из организацијског неуспеха, спољних притисака или експанзионистичке политике организације. 19

Студије о иновацијама у војним пословима су суштински и епистемолошки фокусиране на разумевање и описивање квалитативних побољшања ефикасности оружаних снага ради постизања компаративне предности у односу на остале оружане снаге и повећања укупне стратешке ефикасности нације. За Колина Греја (Colin Gray) стратешка ефикасност укључује „нето (тј. са противничком димензијом уз коју се узме у обзир) ефикасност великог стратешког учинка, а то значи понашања релевантна за претњу или стварну употребу силе“.20

Већина аутора, позивајући се на ове дефиниције и ауторе, иновације у оружаним снагама сагледава у променама начина на који оружане снаге намеравају да реализују своје мисије и задатке у складу са променама стратешког и оперативног окружења и новим способностима за реализацију задатака. Према Адаму Грисому, иновације у оружаним снагама морају имати три карактеристике: иновација мења начин на који оружане снаге реализују мисије, иновација је значајна по обиму и утицају и иновација подразумева већу војну ефикасност. Наведени аутор је значајан за студије о иновацијама у оружаним снагама јер је категорисао четири школе које се баве истраживањима у војним иновацијама. 21

Цивилно-војни модел студија о војним иновацијама тврди да су високи цивилни доносиоци одлука одговорни за иницирање војних иновација уз помоћ одређених и надарених припадника унутар оружаних снага. Цивилно-војни модел у великој мери је повезан са делом Барија Позена, често цитираног као утемељивача ове области студија војних иновација. Његов рад „Извори војне доктрине“ из 1984. године указује на то да однос између ауторитета ван оружаних снага и креативних појединаца у оружаним снагама одређује карактер и степен иновације. Оквир цивилно-војних односа код Позена обједињује наизглед контрастне предлоге структурне реалистичке теорије (равнотеже снага) и организационе теорије, тврдећи да су спољне претње и цивилна интервенција примарне одреднице војних иновација. ${ }^{22}$ Позен и други аутори своје истраживање усредсређују на проблем способности државе да се прилагоди глобалним политичким променама и да благовремено одговори на те промене. На тај начин, промена у доктрини служи и као пут и као замена за способност државе да се прилагоди међународним политичким променама. Ипак, постоје проблеми који директно повезују доктрину са иновативношћу организације. Можда је најпроблематичније то што промена доктрине понекад може да буде само

19 Бери Позен, Извори војне доктрине, ВИНЦ, Београд, 1992.

${ }^{20}$ Colin S. Gray, Strategy For Chaos: Revolutions in Military Affairs and the Evidence of History, Frank Cass, London, 2002, p. 6.

${ }^{21}$ Adam Grissom, „The Future of Military Innovation Studies“, The Journal of Strategic Studies 29, No. 5 October 2006, pp 905-934

22 Бери Позен, Извори војне доктрине, ВИНЦ, Београд, 1992. 
иновација у појмовно-категоријалном речнику који користи доктрина, а да се суштински не мења начин деловања оружаних снага. Поред тога, разумевање доктрине и њено формулисање нема исто значење у теорији и пракси различитих војних организација.

Други студиј односи се на модел међувидовског ривалства у ОС САД, који се приписује Ендрју Бејкевичу (Andrew J. Bacevich), иако заправо нису неуобичајени у другим студијама развоја америчких програма наоружања током Хладног рата. ${ }^{23}$ Овај модел наглашава начин на који ривалство међу видовима ОС САД утиче и на иновације и перцепцију могућег оружаног сукоба. Видови оружаних снага: морнарица, маринци, ваздухопловне снаге, копнена војска и снаге специјалних операција морају се такмичити за доделу буџета, контролу ресурса и власништво над новим способностима. У време смањења и реструктурирања снага, видови оружаних снага морају иновирати како би демонстрирали своју вредност и одговорност, а самим тим и сачували финансије и ресурсе.

Трећи студиј односи се на модел унутарвидовског надметања родова војске, који представља кључни покретач иновације. Ова школа мишљења увелико је повезана са радом Стефена Росена (Stephen P. Rosen), који је тврдио да се успешна иновација увелико ослања на оно што он назива „усклађивање“ лидерства, родова OC и институционалних структура. Росен је тврдио да се „нова теорија о победи“ појављује као резултат надметања идеја између родова ОС. Идеја која добије већу подршку покреће иновацију. 24 Други су даље развили неке од Росенових идеја, а концепт иновације који је повезан са „новом теоријом победе“ ушао је у речник студија о војним иновацијама.

Коначно, четврти модел представља збирку сродних приступа који иновације у оружаним снагама виде као резултат вредности стратешке 25 и организационе културе. ${ }^{26}$ Овај модел, ослоњен на социологију и антропологију, кроз стратешку и организациону културу пружа увид у иновације у војној делатности. Овакав начин размишљања постаје преовлађујући код аутора попут Теа Фарела (Theo G.

23 Andrew J. Bacevich, The Pentomic Era: The US Army between Korea and Vietnam, National Defense University Press, Washington DC, 1986.

24 Stephen P. Rosen, Winning the Next War: Innovation and the Modern Military, Cornell University Press, Ithaca NY, 1991.

25 У најширем смислу, стратешка култура део је свеукупне националне и, у ужем смислу, политичке културе сваке државе. Као таква, она битно утиче на стратешко мишљење и понашање кроз формулацију и имплементацију стратегија, чинећи сваку државу посебном и различитом у односу на друге државе са којима егзистира и корелира у међународним односима. Према: Вељко Благојевић, Стратешка култура и национална безбедност, Зборник Матице српске за друштвене науке, LXX, № 170 (2/2019), стр. 166.

26 Под организационом културом, углавном, подразумева се систем претпоставки, веровања, вредности и норми понашања које су чланови једне организације развили и усвојили кроз заједничко искуство, који су манифестовани кроз симболе и који усмеравају њихово мишљење и понашање. Према: Небојша Јанићијевић, Организационо понашање, Датастатус, Београд, 2008, стр. 301. 
Farrell) и Тери Терифа (Terry Terriff), који објашњавају утицај културе у оружаним снагама на иновације.27 Фарел и Териф, супротно Позеновој неореалистичкој перспективи, која занемарује улогу идеја у обликовању промена у оружаним снагама, тврде да су промене дело људи који нису увек деловали и реаговали логично и линеарно. Закључили су да концепти попут легитимитета организације и идентитета њених чланова могу бити једнако снажни разлози за промене у оружаним снагама као и повећана војна ефикасност.

Студије о организационој култури показале су се посебно ваљаним у решавању неких видљивих недостатака у разумевању начина на који се оружане снаге мењају. Један од најјачих заговорника утицаја културе Дима Адамски (Dima Adamsky) показује како стратешка култура врши утицај на сваку од компоненти борбене моћи: моралну, физичку и концептуалну. Упоредна анализа Диме Адамског о иновацијама у оружаним снагама у САД-у, Израелу и Русији одличан је пример.28 Рад Адамског показује како су различите стратешке културе сваке државе, не само довеле до различитих технолошких путева, већ и до различитих схватања значаја технолошких открића. Као што Адамски доказује, стратешка култура може бити толико утицајна да индукује готово потпуно обрнут однос између способности концепције, развоја и постизања технолошких пробоја и способности препознавања њиховог значаја. Адамски објашњава како стратешка култура утиче на оружане снаге одређеним карактеристикама које су последично обликовале развој, употребу и перцепцију саме природе технологије. Једнако је важно разумети да свака култура има различите предности и недостатке и да не постоје савршене оружане снаге. Компромиси су уграђени у саму структуру свих оружаних снага, јер су њихове стратешке културе одређене избором донесеним као одговор на стално развијање сложених односа између међународног окружења, државе, друштва и њих самих. За разумевање иновација у оружаним снагама битно је уочити да осим што организациона култура у оружаним снагама поседује доминантне вредности хијерархијског модела културе, у њеном оквиру постоје вредности културе као што су иновативност, креативност, предузетништво и праћење стратешког и оперативног окружења. Проблем је у томе што су вредности ових ентитета надјачане доминантним вредностима које желе да сачувају постојеће стање, јер су оне, заједно са опрезом и страхом од промена, у складу са природном инерцијом великог система. Другим речима, и културне норме и професионалне традиције постављају контекст за иновације у оружаним снагама, у основи обликујући организационе изборе, преференције и реакције на технолошке и стратешке могућности. Мајкл Раска (Michael Raska) наводи да три одабрана механизма могу дефинисати овај процес: (1) стратешки

27 Theo G. Farrell and Terry Terriff, The Sources of Military Change: culture, politics, technology, Lynne Rienner, Boulder Colorado, 2002.

28 Dima Adamsky, The Culture of Military Innovation: The Impact of Cultural Factors on the Revolution in Military Affairs in Russia, the US, and Israel, Stanford University Press, Stanford CA, 2010. 
лидери могу планирати и усмеравати оружане снаге ка иновацијама кроз промене у стратешкој мисли; (2) спољни утицаји могу покренути процес културних промена; и (3) међудржавне норме могу обликовати путеве и обрасце прилагођавања оружаних снага. ${ }^{29}$

Студије о иновацијама у оружаним снагама често указују на три врсте институционалних баријера за иновације: организациона крутост, бирократска политика и организациона култура. Према организационој теорији коју заступа Бери Поузен, оружане снаге функционишу као велике, сложене и функционално специјализоване бирократије, дајући предност предвидивости, стабилности и сигурности. ${ }^{30}$

Заједно са институционализованим стандардним оперативним процедурама, основним мисијама, циљевима, стратегијама и структурним нормама, ови фактори појачавају војну стагнацију. Оружане снаге теже да заштите своје интересе у окружењу оскудних ресурса, што јача њихову аверзију и отпор према променама. Стога се иновације које не представљају претњу мисији, ресурсима и аутономији оружаних снага лако усвајају, док оне иновације које се нарушавају аутономију оружаних снага наилазе на снажан отпор. Супротно томе, теоретичари који заступају модел утицаја културе као препреке за иновацију виде вредности стратешке и организационе културе. Док стратешка култура обликује идеје о употреби силе у држави кроз њихова историјска искуства и научене лекције, организациона култура састоји се од идентитета, норми и вредности које су оружане снаге интернализовале у својим прописима, обуци, рутини и пракси. Стога стратешка култура условљава унапред створене појмове о карактеру и вођењу рата и служи истовремено као средство или ограничење у ефикасности организационог учења, прилагођавања и иновација. На крају, спровођење и управљање иновацијама у оружаним снагама, како тврди група аутора корпорације RAND, не настаје у вакууму. Ови аутори тврде да културне, бирократске и организационе препреке иновацијама у оружаним снагама, појачане геостратешким, политичким, економским и оперативним факторима, обликују способност државе да генерише војну моћ. 31

\section{ПРЕДВИЪАЊЕ И ПРИЛАГОЪАВАЊЕ}

Дима Адамски тврди да се оружане снаге мењају кроз два комплементарна процеса. ${ }^{32}$ Први процес је резултат предвиђања који се одвија за време мира. Овај

\footnotetext{
${ }^{29}$ Michael Raska, Military Inovation In Small States, Routledge, New York, 2016, p 4.

30 Бери Позен, Извори војне доктрине, ВИНЦ, Београд, 1992.

31 Jeffrey Isaacson, Christopher Layne, and John Arquilla. Predicting Military Innovation, RAND, Santa Monica, CA, 1999, https://www.rand.org/pubs/documented_briefings/DB242.html $(16 / 09 / 2020)$

32 Dima Adamsky, Israeli Culture of Innovation Between Anticipation and Adaptation, July 2019 https://www.idf.il/media/57915/דימה-אדמסקי-אנגלית.pdf (29/09/20200
} 
процес почива на истраживањима променљивог карактера рата којима се предвиђају обриси будућег ратишта, а затим се из овог општег схватања развијају нови концепти будућих операција, дефинишу се потребне способности, планирају, програмирају, буџетирају програми набавки и по потреби мења организациона структура оружаних снага. Таква врста иновација обично потиче из највишег ешалона у организацији оружаних снага, јер захтева свеобухватан преглед трендова развоја способности оружаних снага и потенцијалних претњи у дугорочном периоду у променљивом стратешком окружењу. Сходно томе, иновација предвиђањем настаје на дедуктиван начин, развија се у режиму „одозго-надоле“ и укључује много маште, системског размишљања и холистичког схватања стварности.

Прилагођавање представља алтернативни приступ иновацији у војној делатности. Овај процес је резултат напора у рату и заснива се на знању о јазу између начина на који се припрема за рат и његових стварних захтева. Ово знање се производи „одоздо према горе“ кроз тактичко-оперативно „трење“ на бојном пољу, што омогућава процес научених лекција и евентуално прилагођавање концепата деловања, организационих структура и стварања нових способности након тога. Ова иновација је реактивна и индуктивна по природи и стога је названа прилагођавањем.

Сваки од приступа има своје предности и недостатке. Предвиђање подразумева институционалну и интелектуалну склоност да се замисли највероватнија будућност. Почива на одржавању одређене интелектуалне климе и одржавању систематског истраживања промена у оперативном и стратешком окружењу од стране релативно мале групе посвећених истраживача - практичара. Ако постигну висок степен релевантности у предвиђању дугорочних трендова, онда је могуће са великом вероватноћом унапред осигурати припрему оружаних снага за будуће претње и евентуални рат. Међутим, предвиђање подразумева велики број грешака. Пошто се неизвесност не може у потпуности елиминисати, велика је вероватноћа да ће визија бити нејасна и непотпуна, пре него детаљна, прецизна или предиктивна. Супротно томе, прилагођавање не трпи неизвесност. Будући да се догађа у ратним временима, провера реалности брзо указује на неусклађеност између постојећих војних способности и захтева стварног бојног поља. Као таква, иновација кроз прилагођавање има користи од јасног разумевања, где постоји потреба да се премости јаз између „замишљеног“ и стварног рата. Недостаци овог процеса су прећутно прихватање реактивности, толеранција према могућности изненађења и најважније, захтев да се истовремено води рат и трансформација способности.

Синхронизација ове две врсте иновација омогућава постизање веће ефикасности, па је равнотежа између њих од суштинског значаја за оружане снаге. Прелазак у било који екстрем једне од ових иновација може довести до фаталних последица за оружане снаге. Прекомеран нагласак на војној футурологији може бити контрапродуктиван јер може резултирати техноцентричним приступом стратегији и евентуалном „самозаваравању“, што умањује способност критичког размишљања о сопственим способностима на бојном пољу. Слично томе, 
недовољно улагање у предвиђање будућности могло би бити подједнако штетно. Оружане снаге морају стално улагати значајну интелектуалну енергију у истраживање карактеристика потенцијалног будућег сукоба у којем могу учествовати. Чињеница да су пророчанске прогнозе у војним пословима проблематичне не би смела одвратити посленике војне мисли и практичаре од интелектуалних настојања да истраже будућност. Иако би фасцинација замишљањем „следећег рата“ могла прерасти у опасну професионалну патологију, припреме за рат и размишљање о њему морају почети пре него што се „рат“ заправо догоди. У супротном, оружане снаге могу постати неефикасан инструмент националне моћи.

Ниједан од ова два идеална типа иновација не егзистира у свом чистом облику. Развој војне мисли, бар у њеном идеалном смислу, требао би бити дијалектички и циклични процес. Војни мислиоци предвиђају садржаје будућег рата, а када се њихове хипотезе сусретну са стварношћу рата, прилагођавање ступа на сцену. На крају, најбоље праксе прилагођавања пронађу свој пут до војних мислилаца и оних који пишу војну доктрину и постају кодификоване као постулати војне теорије, све док она не испуни нови круг провере у ратној стварности. Оружане снаге унутар различитих стратешких култура стварају различите равнотеже између два приступа иновацијама и историјски показују или већу склоност предвиђању или прилагођавању. Револуције у војним пословима указују на потребу равнотеже и важности баланса између војног футуризма, који омогућава предвиђање променљивог карактера рата и склоности ка одржавању организационе и концептуалне флексибилности како би се, по потреби, обезбедило брзо прилагођавање. Оружане снаге треба да осигурају способност иновација тако да предвиде обрисе будућег рата и развију потребне способности како би могле да се прилагоде ако се почетно предвиђање покаже погрешним. Успех у будућем или текућем рату подједнако зависи од способности да се схвати карактер рата, да се развије „нова теорија о победи“ која одговара том карактеру, као и од способности да се оружане снаге прилагоде непредвиђеним збивањима у текућем рату. Процес иновација кроз прилагођавање скупљи је подухват него процес иновација кроз предвиђање, барем што се тиче људских живота. Оружане снаге које акценат дају иновацијама кроз предвиђање вероватно ће улагати мање напора у прилагођавању стварним условима рата.

\section{ИНОВАЦИЈЕ У ОРУЖАНИМ СНАГАМА И СТРАТЕШКО ОКРУЖЕЊЕ}

Иновације у оружаним снагама су нераскидиво повезане са политичким и националним циљевима. ${ }^{33}$ Тако, Елиот Коен (Eliot A. Cohen) тврди да иновације у

33 Jon F. Giese, Military Innovation: Sources of Change for United States Special Operations Forces, Naval Postgraduate School, Monterey, California, December 1999. https://calhoun.nps.edu/bitstream/handle/10945/13431/99Dec_Giese.pdf?sequence=1\&isAl lowed=y 
оружаним снагама произилазе из „прилагођавања војног инструмента политичким циљевима“.34 Како је употреба оружаних снага заснована на политичким одлукама, онда је логично да политички циљеви покрећу и усмеравају иновативне промене у оружаним снагама као средство за постизање таквих циљева. У основи, процес иновација у оружаним снагама често укључује политичко усмеравање, интервенцију и лобирање. Политичка воља, како споља, тако и унутар оружаних снага, може бити важна у процесу иновација. На пример, промене у финансирању могу подстаћи или зауставити иновације. Након почетног развоја нових технологија и тактика, одлука о усвајању и примени дате иновације у неким случајевима захтева политичку вољу. Улога политике у стварању услова да иновације у оружаним снагама буду у функцији стратешке ефикасности и ефективности нације је вишеструка. Носиоци политике у држави треба да изразе јасну политичку и интелектуалну искреност према стратешком контексту и превазиђу изазове јаких тенденција да се стратегија дефинише у смислу садашњих обавеза или „предвидљиве“ будућности. Други задатак носилаца политичког одлучивања је одбацивање заблуде да формулација стратегије националне безбедности и одбране и војне стратегије могу бити вођене штедњом. Учинак штедње на политику је сужавање спектра могућности, што као последицу може имати то да остварење националних интереса буде доведено у питање. И коначно, под све већим притиском да смање јавну потрошњу, државе морају бити спремне да уложе време, интелект и посебно финансијске ресурсе да би изградиле, развиле и очувале динамичнији и флексибилнији однос између стратегије и иновација и притом обезбедиле стратешку агилност и ефикасност.

У стратешком окружењу државе евидентно је надметање у домену концептуалне маште и оперативне домишљатости између потенцијално супротстављених актера или учесника у сукобу који траје. У питањима безбедности и одбране, национална стратегија је увек била интеракција између три компоненте: визије или циља политике; тежње или примена те визије (тј. војна стратегија и операције или „начини“); и додељених ресурса. Као што је приметио Хју Стрејчен (Hew Strachan), стратегија је итеративни процес: „дијалога где циљеви такође одражавају средства, а где је резултат ... компромис између циљева политике и војних средстава доступних за њено спровођење“.35 Због важности оружаних снага за остварење националних интереса, иновације треба посматрати у контексту сложености безбедносних дилема, које утичу на стратешке, организационе и оперативне захтеве у решавању, како тренутних, тако и будућих изазова у стратешком окружењу.

Одабраној стратегији државе за остварење националних интереса, иновације у оружаним снагама морају да омогуће стратешку агилност и створе услове за постизање ефективности и ефикасности у њеној примени. У време велике

34 Eliot A. Cohen, „A Revolution in Warfare“, Foreign Affairs 75, no. 2 (1996), p 16.

35 Hew Strachan, „The Lost Meaning of Strategy“, Survival Vol.47, No.3, Autumn 2005, p.52. 
флуидности у свим стварима које се тичу националне стратегије, сврха иновација у оружаним снагама треба да буде стварање низа опција, од којих креатори политике и стратешки лидери у правом тренутку могу одабрати најприкладнију. Иновације у оружаним снагама могу ову функцију омогућити кроз покушај да обезбеде свестраност у постојећим способностима. Пример за такву врсту иновације су развој или набавка и коришћење вишенаменских платформи за различите системе наоружања и употреба вишенаменских борбених система. Процедуре у иновацијама у оружаним снагама морају да омогуће краће време набавке, испитивања, редизајнирања и преуређивања борбених система, а све како би се осигурало да систем набавки може да произведе војну опрему која је блиска траженим захтевима. Иновације у оружаним снагама треба да теже побољшању изгледа за њихову брзу реконфигурацију и интероперабилност са другим инструментима националне моћи и по потреби оружаним снагама партнерских или савезничких држава.

Карактеристике савременог стратешког окружења указују на то да је потребна промена парадигме у којој иновације у оружаним снагама имају сврху тражења најбољег одговора на дати стратешки проблем или стратешки изазов. Будућност иновација у оружаним снагама огледа се у пружању одговора на проблеме и изазове како се они појаве. Другим речима, иновације не треба поистовећивати са датим стратешким шаблоном или стратешким избором. Уместо тога, иновације треба предузети управо како би се могло, интелигентно и сигурно избећи да буду заробљене у стратешким претпоставкама или одлукама које се покажу погрешним или непотпуним.

Поседовање супериорније способности од потенцијалног противника, која је резултат иновација у оружаним снагама, омогућава више стратешких избора. У савременом стратешком окружењу препознају се четири различите стратегије: (1) стратегија одвраћања; (2) стратегија наметања трошкова; (3) напад на стратегију конкурента; и (4) напад на политички систем конкурента. Стратегија одвраћања заснива се на поседовању супериорније способности ради убеђивања потенцијалног противника да његова одређена акција, попут агресије, не може бити успешна. Наметањем трошкова за развој способности оружаних снага могуће је одвратити потенцијалног противника од тог истог чина и самим тим и од предузимања одређених радњи које могу угрозити националне интересе супериорније стране. Истовремено, таквим стратегијама могуће је потенцијалног противника навести да преусмери ресурсе на наизглед важне, али стратешки небитне економске, политичке и војне потенцијале и тиме му смањити могућност избора начина деловања.

Напад на стратегију конкурента представља покушај сужавања његовог стратешког избора. Историјски пример је развој доктрине америчке Ваздушнокопнене битке током 1970-их и 80-их година, која је убедила Совјетски Савез да одабрана стратегија неће бити довољно ефективна и ефикасна. Тренутно, кинеска стратегија заснована на појачаној способности спречавања интервенције 
или спречавања приступа (A2/AD) ${ }^{36}$ има за циљ да нападне и негира ефикасност америчке стратегије за пројекцију моћи у источној Азији. Коначно, стратегија које напада политички систем конкурента настоји да искористи субверзивне фракције унутар тог система. На пример, током Хладног рата, Америчка стратешка одбрамбена иницијатива (СДИ) појачала је расправе у совјетском руководству о правцу, карактеру и стратешкој корисности такмичења са Сједињеним Америчким Државама у развоју свемирског програма.

Дакле, начини и квалитет иновација у оружаним снагама морају се посматрати у релативном контексту - кроз призму конкурентских стратегија које се огледају у напорима у развијању ефикасних противмера и одговора. Иновације и нове технологије ће све више обликовати стратешке изборе у 21. веку, планирање одбране, управљање и технолошке приоритете, захтевајући способност стратешког и оперативног прилагођавања оружаних снага ради остварења националних интереса.

\section{ЗАКЉУЧАК}

Иновације покрећу развој нових средстава или начина који оружаним снагама омогућавају да предвиде будуће захтеве, и да изврше додељене мисије. Оружане снаге морају иновирати начин на који се обучавају, припремају, планирају операције и боре. Другим речима, иновације су кључне у развоју способности снага и употреби тих способности ради реализације додељених мисија и задатака.

Истраживање, упоређивање, расправе и примена сазнања из студија о иновацијама у оружаним снагама ради покушаја дефинисања начина успостављања потребних способности оружаних снага за остварење националних интереса је изазов савремених држава у тражењу одговора на променљиву стратешку реалност и безбедносне изазове.

Разматрајући иновације у оружаним снагама може се уочити својеврстан парадокс. С једне стране, оружане снаге су традиционално исказивале отпор према променама, одржавајући проверене стратегије и структуре за неговање континуитета усред преовлађујућег процеса институционализације и чињенице да последице грешака суочене са свеприсутном стратешком неизвесношћу могу бити изузетно неповољне по остваривање националних интереса. С друге стране, оружане снаге су препознавале да неуспех у развоју средстава ратне технике и

\footnotetext{
36 Оружје за ускраћивање подручја или систем за заштиту од приступа (eng. area denial weapon or Anti Access/Area Denial - A2/AD) се дефинише као способност и стратегија која се користи за спречавање противника да заузме или пређе неко подручје копна, мора или ваздуха. Специфична метода која се користи не мора бити потпуно ефикасна у спречавању проласка (а понекад и није) све док је довољна да озбиљно ограничи, успори или угрози противника. Према: The Joint Concept for Entry Operations, https://www.jcs.mil/Portals/36/Documents/Doctrine/concepts/jceo.pdf?ver=2017-12-28-

162000-837
} 
начина њихове употребе може довести до пораза и стога су биле мотивисане да траже начине да другачије планирање и извођење војних операција.

Развој способности оружаних снага не може се догодити без иновација. Да би одржале оперативну изврсност, савладале институционалне изазове и спречиле будуће претње националној безбедности, оружане снаге морају да усвоје културу иновације. Иновативне вредности организационе културе пружају могућности за ефикасност оружаних снага. Очување стабилности по цену избегавања иницирања и спровођења промена су карактеристике хијерархијске организационе културе у оружаним снагама. Таква организациона култура, ако се не промени, може имати више негативних ефеката. Прво, постоји могућност да стратешко вођство можда не примети потребу за променом или ће временом такву потребу игнорисати. Друго, велика жеља за стабилношћу може обесхрабрити покушаје иновативног деловања унутар војних организација. Коначно, такав приступ ће довести до стварања генерације лидера са менталним оквиром деловања који ће се снажно залагати за очување постојећег стања, категорички игноришући спознаје да су промене нужне и пожељне. Свака од ових тенденција, ако се настави, резултоваће смањењем ефикасности и ефективности оружаних снага, а самим тим и стратешке ефикасности нације. Стога, стратешко вођство мора пронаћи начин да промени постојећу организациону културу и прилагоди је захтевима динамички променљивог стратешког окружења. Иницирање и спровођење промена у оружаним снагама, које су усклађене са захтевима стратешког окружења, мора бити подржано одговарајућом врстом организационе културе у којој ће, као једна од кључних вредности, бити иновативност и покретање промена.

Иновације су покретач радикалне трансформације војних концепата, процеса, способности и структура. Тешко је замислити оружане снаге које пролазе кроз било који степен трансформације без иновативних идеја које пружају алтернативу досадашњим принципима. Трансформација је управо та промена толико значајна да актуелну парадигму чини застарелом. Свака иновација у том погледу темељно мења начин на који се воде операције и ратови и проузрокује неравнотежу између конкурентских стратегија.

\section{БИБЛИОГРАФИЈА:}

1. Adamsky Dima, The Culture of Military Innovation: The Impact of Cultural Factors on the Revolution in Military Affairs in Russia, the US, and Israel, Stanford University Press, Stanford CA, 2010.

2. Adamsky Dima, Israeli Culture of Innovation between Anticipation and Adaptation, July 2019. преузето 29.09.2020. ca https://www.idf.il/media/57915/אדמסקי-דימהאנגלית.pdf

3. Bacevich Andrew J., The Pentomic Era: The US Army between Korea and Vietnam, National Defense University Press, Washington DC, 1986.

4. Christenssen Clayton, The Innovator's Dilemma: When New Technologies Cause Great Firms to Fail, MA: Harvard Business School Press, Boston, 1997.

5. Cohen Eliot A., „A Revolution in Warfare”, Foreign Affairs 75, no. 2, 1996. 
6. Вељко Благојевић, Стратешка култура и национална безбедност, Зборник Матице српске за друштвене науке, LXX, № 170 (2/2019)

7. Небојша Јанићијевић, Организационо понашање, Датастатус, Београд, 2008.

8. Farrell Theo G. and Terriff Terry, The Sources of Military Change: culture, politics, technology, Lynne Rienner, Boulder Colorado, 2002.

9. Garstka John J., „Conceptual Framework for Innovation in Capability Development“, Crosscutting Issues in International Transformation: Interactions and Innovations among People, Organizations, Processes, and Technology, ed. Derrick Neal, Henrik Friman, Ralph Doughty, and Linton Wells II, 21-5, Center for Technology and National Security Policy, Washington, DC, 2009.

10. Gat Azar, The Development of Military Thought: The Fourteenth Century, Oxford University Press, New York, 1991.

11. Giese Jon F., Military Innovation: Sources of Change for United States Special Operations Forces, Naval Postgraduate School, Monterey, California, December 1999.

https://calhoun.nps.edu/bitstream/handle/10945/13431/99Dec_Giese.pdf?sequenc $\mathrm{e}=1$ \&isAllowed $=\mathrm{y}$

12. Gray Colin S., Strategy For Chaos: Revolutions in Military Affairs and the Evidence of History, Frank Cass, London, 2002.

13. Grissom Adam, „The Future of Military Innovation Studies“, The Journal of Strategic Studies 29, No. 5 October 2006.

14. Grissom Adam, „The Future of Military Innovation Studies“, The Journal of Strategic Studies 29, No. 5 October 2006.

15. Isaacson Jeffrey, Layne Christopher, and Arquilla John. Predicting Military Innovation, RAND, Santa Monica, CA, 1999. преузето 16.09.2020. са https://www.rand.org/pubs/documented_briefings/DB242.html

16. Raska Michael, Military Inovation In Small States, Routledge, New York, 2016.

17. Stephen J. Gerras, Strategic Leadership Primer 3rd Edition, US Army War College, Carlisle $\quad$ Barracks, 2010, преузето 20.09.2020. са https://publications.armywarcollege.edu/pubs/3516.pdf

18. Stephen P. Rosen, Winning the Next War: Innovation and the Modern Military, Cornell University Press, Ithaca NY, 1991.

19. Strachan Hew, „The Lost Meaning of Strategy“, Survival Vol.47, No.3, Autumn 2005.

20. Von Clausewitz Carl, On War, Edited and Translated by Michael Howard and Peter Paret,Princeton University Press, Princeton, New Jersey, 1989.

21. Watts Barry and Murray Williamson, „Military Innovation in Peacetim“ in Williamson Murray and Allan R. Millett (eds.), Military Innovation in the Interwar Period, Cambridge University Press, New York, 1996.

22. Joint Doctrine Development System CJCSI 5120.02C; http://www.jcs.mil>pubs.pdf

23. The Joint Concept for Entry Operations, https://www.jcs.mil/Portals/36/Documents/Doctrine/concepts/jceo.pdf?ver=201712-28- 162000-837

24. Yarger Harry R., Strategic Theory for The 21st Century: The Little Book On Big Strategy, February 2006, преузето 17.09.2020. са https://www.files.ethz.ch/isn/20753/Strategic\%20Theory\%20for\%20the\%2021st \%20Century.pdf

25. Пенезић Ненад, Предузетништво - савремени приступ, Академска књига, Нови Сад, 2008.

26. Позен Бери, Извори војне доктрине, ВИНЦ, Београд, 1992. 
27. Покрајац Слободан, Менаџмент промена и промене менаџмента, Тору, Београд, 2001.

28. Тофлер Алвин и Хајди, Рат и антират, Паидеиа, Београд, 1998.

\section{MILITARY INNOVATION AS A PREREQUISITE FOR STRENGTHENING THE NATION'S STRATEGIC EFFICIENCY}

One of the contemporary challenges facing states is adapting to complex changes in the strategic environment. The contribution of strategic studies in facing this challenge is reflected in the study of the sources, methods and patterns of innovation in the armed forces. Armed forces as an instrument of national power have great importance for the preservation of national security, so innovations, although insufficient, are certainly necessary. Innovations in the armed forces have become a special part in the strategic studies that deal with research on changes when it comes to understanding and adapting to new ways of using forces. The key questions are: when, how and why do armed forces change, what are the internal and external factors that determine the ways of innovation in military activities, what is the relationship between innovation and the strategic environment, what and how determines the success of innovation? The response of armed forces can no longer be just adapting certain parts and systems to new changes, but armed forces must develop the ability to innovate which will help them master the new paradigm in defense and protection of national interests in order to respond to constant changes in strategic environment. The authors point out that without innovation there are no necessary capabilities of the armed forces and that there is a need for their academic study in order to increase the overall strategic efficiency of the nation.

Keywords: innovation, armed forces, strategy, strategic environment, strategic efficiency of the nation 